\title{
Valsartan lowers brain $\beta$-amyloid protein levels and improves spatial learning in a mouse model of Alzheimer disease
}

\author{
Jun Wang, ${ }^{1}$ Lap Ho, ${ }^{1,2}$ Linghong Chen, ${ }^{1}$ Zhong Zhao, ${ }^{1}$ Wei Zhao, ${ }^{1}$ Xianjuan Qian, ${ }^{1}$ Nelson Humala, ${ }^{1}$ \\ Ilana Seror, ${ }^{1}$ Sadie Bartholomew, ${ }^{1}$ Clive Rosendorff, ${ }^{3}$ and Giulio Maria Pasinetti1,2,4

\begin{abstract}
${ }^{1}$ Department of Psychiatry, Mount Sinai School of Medicine, New York, New York, USA. ${ }^{2}$ Geriatric Research Education and Clinical Center, James J. Peters Veterans Affairs Medical Center, New York, New York, USA. 3Department of Medicine, Mount Sinai School of Medicine and the James J. Peters Veterans Affairs Medical Center, New York, New York, USA. ${ }^{4}$ Department of Neuroscience, Mount Sinai School of Medicine, New York, New York, USA.
\end{abstract}

\begin{abstract}
Recent epidemiological evidence suggests that some antihypertensive medications may reduce the risk for Alzheimer disease (AD). We screened 55 clinically prescribed antihypertensive medications for AD-modifying activity using primary cortico-hippocampal neuron cultures generated from the Tg2576 AD mouse model. These agents represent all drug classes used for hypertension pharmacotherapy. We identified 7 candidate antihypertensive agents that significantly reduced $A D$-type $\beta$-amyloid protein $(A \beta)$ accumulation. Through in vitro studies, we found that only 1 of the candidate drugs, valsartan, was capable of attenuating oligomerization of $A \beta$ peptides into high-molecular-weight (HMW) oligomeric peptides, known to be involved in cognitive deterioration. We found that preventive treatment of Tg2576 mice with valsartan significantly reduced AD-type neuropathology and the content of soluble HMW extracellular oligomeric A $\beta$ peptides in the brain. Most importantly, valsartan administration also attenuated the development of $A \beta$-mediated cognitive deterioration, even when delivered at a dose about 2-fold lower than that used for hypertension treatment in humans. These preclinical studies suggest that certain antihypertensive drugs may have $\mathrm{AD}$-modifying activity and may protect against progressive $A \beta$-related memory deficits in subjects with $A D$ or in those at high risk of developing $A D$.
\end{abstract}

\section{Introduction}

Recent evidence suggests that the use of certain antihypertensive drugs may decrease the incidence of AD (1-4). For example, based on their analysis of the Cochrane Dementia and Cognitive Improvement Group's Specialized Register (containing reports of trials from all major medical databases), Lopez-Arrieta and Birks (1) reported that the dihydropyridine $\mathrm{Ca}^{2+}$ channel receptor antagonist nimodipine decreases the incidence of $\mathrm{AD}$ in subjects with hypertension. Additionally, the double-blind placebo-controlled Systolic Hypertension in Europe Trial reported that longterm antihypertensive therapy with nitrendipine, another $\mathrm{Ca}^{2+}$ channel receptor blocker, reduced the risk of dementia, primarily AD-type, in hypertensive cases after a median follow-up of 2 years (4), while Guo et al. (3) reported that the combination of certain $\beta$-adrenergic blockers and dihydropyridine $\mathrm{Ca}^{2+}$ channel receptor antagonists protected elderly hypertensive subjects from developing AD. Last, the Cache County Study of Memory and Aging concluded that the use of antihypertensive medications is associated with a reduced incidence of $\mathrm{AD}$ among subjects 65 years of age and older, with the greatest reduction seen in the use of $\mathrm{K}^{+}$-sparing diuretics (2).

Despite this encouraging evidence, other studies have failed to support the efficacy of antihypertensive agents in AD dementia. In particular, the Rotterdam study reported that the use of antihypertensive drugs did not significantly affect the relative risk

Nonstandard abbreviations used: $A \beta, \beta$-amyloid protein; $A D$, Alzheimer disease; $\mathrm{APP}$, amyloid precursor protein; ARB, angiotensin II type 1 receptor blocker; $\mathrm{CM}$, cell membrane; CTF, carboxyterminal fragment; ECE-1, endothelin-converting enzyme-1; HMW, high-molecular-weight; IDE, insulin-degrading enzyme; MWM, Morris water maze; sAPP, soluble APP.

Conflict of interest: The authors have declared that no conflict of interest exists. Citation for this article: J. Clin. Invest. 117:3393-3402 (2007). doi:10.1172/JCI31547. for developing $\mathrm{AD}$ among 7,046 elderly subjects who were free of dementia at baseline (5). Moreover, several randomized trials for the prevention of cardiovascular disease (e.g., Systolic Hypertension in the Elderly Program [SHEP; ref. 6], the Medical Research Council [MRC] trial [ref. 7], and the Study on Cognition and Prognosis in the Elderly [SCOPE; ref. 8]) concluded that the use of certain $\beta$-adrenergic blockers, thiazide diuretics, or angiotensin II type 1 receptor blockers (ARBs; e.g., candesartan), respectively, did not improve cognitive performance. Thus, at present there is inconsistent evidence regarding the influence of antihypertensive drugs on $\mathrm{AD}$ incidence and/or pathogenesis.

In an effort to clarify this discrepancy, we carried out a highthroughput drug screening to test the hypothesis that antihypertensive drugs might influence $\mathrm{AD}$ through mechanisms affecting $\beta$-amyloid protein (A $\beta$ ) neuropathology, independent of blood pressure-lowering activity. Abnormal accumulations of $\mathrm{A} \beta$ peptides in the brain are associated with a cascade of cellular events resulting in cognitive decline (9). A $\beta$ species with different amino and carboxyl termini are generated from the ubiquitously expressed amyloid precursor protein (APP) through sequential proteolysis by $\beta$ - and $\gamma$-secretases (10-12). A third proteolytic enzyme, $\alpha$-secretase, may reduce $A \beta$ generation by cleavage of APP within the A $\beta$ peptide sequence (13). While aggregation and precipitation of $A \beta$ peptides into extracellular amyloid plaque deposits in the brain are key pathological features of $\mathrm{AD}$, recent studies indicate that accumulations of soluble high-molecularweight (HMW) extracellular oligomeric $A \beta$ species, rather than deposition of amyloid per se, might be specifically related to spatial memory reference deficits (14-19).

We report that certain antihypertensive drugs are able to lower $A \beta$ in vitro. We also found that the ARB valsartan is able to lower $\mathrm{A} \beta$ and inhibit $\mathrm{A} \beta$ oligomerization into soluble HMW extracellular 
species in vivo. These effects were seen even at a dose equivalent to approximately 2 -fold lower than that commonly prescribed for the treatment of hypertension in humans. The functional relevance of this finding was confirmed by evidence that valsartan's A $\beta$-lowering activity in the brain coincided with attenuation of spatial memory reference deficits in Tg2576 mice, in the absence of detectable blood pressure-lowering activity.

\section{Results}

Identification of antibypertensive drugs with AD-modifying properties. Our high-throughput screening study assessed 55 antihypertensive drugs representing all pharmacological classes of currently available antihypertensives (see Complete list of 55 commonly prescribed antibypertensive drugs). We found that 7 of the 55 agents significantly reduced the accumulation of $A \beta_{1-40}$ and $A \beta_{1-42}$ in primary embryonic cortico-hippocampal neuron cultures derived from the Tg2576 mouse AD model (20). A $\beta$ reductions were observed in a dose-dependent fashion (Table 1 ). The predicted drug concentrations resulting in a $50 \%$ inhibition of steady-state $\mathrm{A} \beta$ peptide levels $\left(\mathrm{EC}_{50}\right)$ in the conditioned medium were calculated at a micromolar range (Table 1$)$. No neurotoxicity was detected with any of the 7 agents, as assessed by lactate dehydrogenase (LDH) activity at drug concentrations up to $10 \mu \mathrm{M}$ (Table 1$)$.

The $7 \mathrm{~A} \beta$-lowering antihypertensive agents found to be effective in attenuating the accumulation of $A \beta_{1-40}$ and $A \beta_{1-42}$ are not specific to any single pharmacological class or clinical indication (see Complete list of 55 commonly prescribed antibypertensive drugs). The drugs belong to 6 different pharmacological subclasses, all of which are prescribed for the treatment of hypertension: (a) propranolol HCl, a $\beta$-adrenergic blocker; (b) carvedilol, an $\alpha / \beta$-adrenergic blocker; (c) valsartan and losartan, ARBs; (d) nicardipine $\mathrm{HCl}$, a $\mathrm{Ca}^{2+}$ channel blocker; (e) amiloride $\mathrm{HCl}$, a $\mathrm{K}^{+}$-sparing diuretic; and (e) hydralazine $\mathrm{HCl}$, a vasodilator (see Complete list of $55 \mathrm{com}$ monly prescribed antibypertensive drugs).

Recent evidence indicates that spatial memory reference deficits in $\operatorname{Tg} 2576$ mice are primarily influenced by the accumulation of soluble, extracellular HMW A $\beta$ species, rather than the deposition of total guanidine-extractable $\mathrm{A} \beta$ peptides in the $\mathrm{AD}$-type amyloid plaques in the brain (15). Based on this evidence, we investigated the role of the 7 identified antihypertensive drugs in preventing $A \beta$ oligomerization into soluble HMW species in vitro.

Using an established in vitro oligomerization assay (21), we found that among the 7 drugs identified, valsartan $(100 \mu \mathrm{M})$ significantly reduced the accumulation of HMW A $\beta$ peptide species, while losartan was effective to a lesser extent. In contrast, propranolol $\mathrm{HCl}$, carvedilol, nicardipine $\mathrm{HCl}$, amiloride $\mathrm{HCl}$, and hydralazine $\mathrm{HCl}$ had no effect on $\mathrm{A} \beta$ oligomerization (Figure $1 \mathrm{~A}$ ). Quantitative analysis showed that valsartan $(10 \mu \mathrm{M})$ significantly prevented, by greater than 5-fold, the oligomerization of $A \beta_{1-42}$ (and $A \beta_{1-40}$; data not shown) into a HMW (>40 kDa) A $\beta$ peptide species relative to vehicle-treated control peptides, as assessed by Western blot assay in vitro (Figure 1B). Consistent with this evidence, using a dot blot immunoassay with an antibody (A11) that selectively detects HMW A $\beta$ species with molecular masses greater than $40 \mathrm{kDa}(22)$, we found that valsartan prevented $A \beta_{1-42}$ oligomerization in vitro, relative to vehicle-treated peptides (Figure 1C), 24 hours after incubation.

Compared with other antihypertensive compounds that we found to lower $A \beta$, valsartan had stronger in vitro anti-A $\beta$ oligo-
Complete list of 55 commonly prescribed antihypertensive drugs screened for potential $A \beta$-lowering activity, in vitro

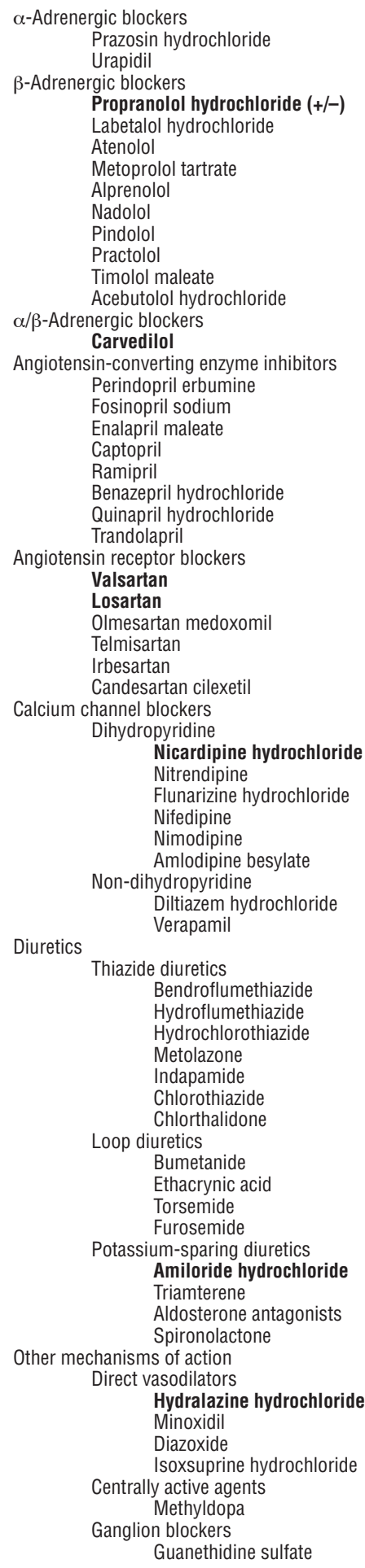

All drugs were obtained as part of the Spectrum Collection from MicroSource Discovery Systems Inc. The 55 antihypertensive agents are listed in 8 pharmacological classes $(24,39)$. Potential A $\beta$-lowering activity was assessed using primary cortico-hippocampal neuron cultures derived from embryonic (E15) Tg2576 AD mice. In the highthroughput dose-response screening studies, the 7 drugs shown in boldface were found to exert significant $A \beta$-lowering activity, in the absence of cellular toxicity. 
Table 1

Identification of 7 antihypertensive drugs with A $\beta$-lowering activity in vitro

\begin{tabular}{|c|c|c|c|}
\hline & \multicolumn{2}{|c|}{$\mathrm{EC}_{50}(\mathrm{M})$ : $\mathrm{A} \beta$-lowering activity } & \multirow{2}{*}{$\begin{array}{c}\text { LDH } \\
\left.\text { (at } 1 \times 10^{-5} \mathrm{M}\right)\end{array}$} \\
\hline & $\mathrm{A} \beta_{1-40}$ & $A \beta_{1-42}$ & \\
\hline \multicolumn{4}{|l|}{$\beta$-Adrenergic blocker } \\
\hline Propranolol HCl (+/-) & $5.75 \times 10^{-5}$ & $4.68 \times 10^{-5}$ & No change \\
\hline \multicolumn{4}{|l|}{$\alpha / \beta$-Adrenergic blocker } \\
\hline Carvedilol & $6.61 \times 10^{-5}$ & $7.02 \times 10^{-4}$ & No change \\
\hline \multicolumn{4}{|c|}{ Angiotensin receptor blockers } \\
\hline Valsartan & $1.44 \times 10^{-5}$ & $1.79 \times 10^{-5}$ & No change \\
\hline Losartan & $7.82 \times 10^{-5}$ & $5.12 \times 10^{-5}$ & No change \\
\hline \multicolumn{4}{|l|}{ Calcium blocker } \\
\hline Nicardipine $\mathrm{HCl}$ & $3.64 \times 10^{-5}$ & $6.97 \times 10^{-5}$ & No change \\
\hline \multicolumn{4}{|l|}{ Diuretic } \\
\hline Amiloride $\mathrm{HCl}$ & $8.67 \times 10^{-5}$ & $3.01 \times 10^{-5}$ & No change \\
\hline \multicolumn{4}{|l|}{ Vasodilator } \\
\hline Hydralazine $\mathrm{HCl}$ & $9.29 \times 10^{-6}$ & $1.04 \times 10^{-5}$ & No change \\
\hline \multicolumn{4}{|c|}{$\begin{array}{l}\text { Among the } 55 \text { clinically prescribed antihypertensive drugs, } 7 \text { drugs showed a dose-depen- } \\
\text { dent } A \beta \text {-lowering activity without exerting neurotoxicity as evaluated by LDH assay. The drug } \\
\text { dose-response curve was analyzed using sigmoid dose-response (variable hillslope) nonlin- } \\
\text { ear fitting method (Prism Software; GraphPad Software). } E C_{50} \text { values were derived from the } \\
\text { equation: } y=\text { lowest } A \beta \text { level + (highest } A \beta \text { level - lowest } A \beta \text { level) } /\left(1+10^{\wedge}\left[\left(\text { logE } C_{50}-x\right) \times\right.\right. \\
\text { hillslope]), where the } x \text { value is logarithm of drug concentration and the } y \text { value is } A \beta \text { level. } \\
\text { LDH, lactate dehydrogenase. }\end{array}$} \\
\hline
\end{tabular}

to untreated age- and sex-matched Tg2576 control mice, after approximately 5 months of chronic treatment (Figure 2D). These data are consistent with a previous report that valsartan has no effect on normotensive rats (23).

In further control studies, we confirmed that adult (6-7 months old) Tg2576 mice are normotensive compared with strain-, age-, and sexmatched WT mice (Figure 2E).

Valsartan treatment attenuates AD-type cognitive deterioration coincidental with the prevention of $A \beta$ oligomerization into soluble HMW extracellular species. The Tg2576 AD mouse model is well known to develop progressive $A \beta$-associated cognitive deterioration with increasing age (25). As expected, our study demonstrated that untreated control, 11-month old Tg2576 mice showed impaired acquisition of spatial learning, as assessed by the Morris water maze (MWM) test (26). The mice failed to learn to use the available visual cues to help locate a submerged escape platform, as indicated by the lack of significant improvements in the escape latency across consecutive learning trials (Figure 3A).

After treatment with valsartan, $\operatorname{Tg} 2576$ mice were able to locate the escape platform, as demonstrated by significantly reduced escape latency with progressive learning trials (Figure 3A), even when valsartan was delivered at dose equivalents approximately 2 -fold lower that those commonly pre-

merization activity. Because of this consideration and the good tolerability and safety record of valsartan in the treatment of hypertension (23), we proceeded with a series of in vivo studies to assess any functional beneficial role of the agent in preventing $\mathrm{AD}$-type spatial memory reference deficits and $\mathrm{A} \beta$ neuropathology in adult $\operatorname{Tg} 2576$ mice.

Chronic valsartan treatment is well tolerated in $\mathrm{Tg} 2576$ mice. The recommended dose of valsartan for the treatment of hypertension in humans is $80-320 \mathrm{mg} / \mathrm{d}(24)$. This range corresponds to approximately $20-60 \mathrm{mg} / \mathrm{kg} / \mathrm{d}$ in mouse, as derived using FDA criteria for converting drug equivalent dosages across species, based on body surface area ([human equivalent dose in $\mathrm{mg} / \mathrm{kg}=$ animal dose in $\mathrm{mg} / \mathrm{kg} \times(\text { animal weight in } \mathrm{kg} / \text { human weight in } \mathrm{kg})^{0.33}$; http:// www.fda.gov/cber/gdlns/dose.htm). Because the overall goal of our study was to test the hypothesis that certain antihypertensive drugs may influence AD-type amyloid pathogenesis independent of blood pressure-lowering activity, we treated Tg2576 mice with either 10 or $40 \mathrm{mg} / \mathrm{kg} / \mathrm{d}$ of valsartan, doses either approximately 2 -fold below or within the recommended human equivalent dosage range (55 and $220 \mathrm{mg} / \mathrm{d}$, respectively).

We found that chronic valsartan treatment for approximately 5 months in Tg2576 mice, delivered in the drinking water at either 10 or $40 \mathrm{mg} / \mathrm{kg} / \mathrm{d}$, did not significantly influence animal body weight (Figure 2A), daily fluid consumption (Figure 2B), or general metabolic status, as reflected by glucose tolerance responses (Figure 2C), assessed at approximately 11 months of age.

When we tested the potential influence of valsartan on modifications in blood pressure in $\operatorname{Tg} 2576$ mice, we found that valsartan delivered at either 10 or $40 \mathrm{mg} / \mathrm{kg} / \mathrm{d}$ failed to produce a statistically significant change in either systolic, diastolic, or mean arterial blood pressure in normotensive $\operatorname{Tg} 2576$ mice (see below), relative scribed for the treatment of hypertension in humans $(10 \mathrm{mg} / \mathrm{kg} / \mathrm{d})$ $\left(F_{1,7793}=4.913, P=0.0288\right.$ for drug treatment; $F_{7,23660}=2.131$, $P=0.0466$ for escape latency).

$\mathrm{Tg} 2576$ mice treated with $40 \mathrm{mg} / \mathrm{kg} / \mathrm{d}$ of valsartan, a dose equivalent to that commonly used for the treatment of hypertension in humans, also performed significantly better than untreated mice $\left(\mathrm{F}_{1,19840}=14.28, P=0.0003\right.$ for drug treatment; $\mathrm{F}_{7,34510}=3.549$, $P=0.0018$ for escape latency) (Figure $3 \mathrm{~A})$. The 2 valsartan-treated groups $(10 \mathrm{mg} / \mathrm{kg} / \mathrm{d}$ vs. $40 \mathrm{mg} / \mathrm{kg} / \mathrm{d})$ did not show significant differences in their MWM behavior test performance $(P=0.08)$.

In additional parallel studies using the MWM behavior test, we confirmed that the 2 doses of valsartan treatment $(10 \mathrm{mg} / \mathrm{kg} / \mathrm{d}$ and $40 \mathrm{mg} / \mathrm{kg} / \mathrm{d}$ ) not only significantly promoted the learning acquisition during the hidden-platform learning trial but also significantly promoted spatial memory retention during the probe trial (Supplemental Figure 2, A and B; supplemental material available online with this article; doi:10.1172/JC31547DS1). The valsartan treatment did not affect the visible platform learning curve, which was used in our study as control for the nonspatial factors (e.g., sensory-motor performance, motivation, etc., on MWM performance); nor did the valsartan treatment affect the swimming ability of the Tg2576 mice, as reflected by their similar swimming speed (Supplemental Figure 2, C and D).

Treatment of strain-, age-, and sex-matched WT mice with 10 or $40 \mathrm{mg} / \mathrm{kg} / \mathrm{d}$ valsartan for approximately 5 months failed to influence spatial reference memory performance on the MWM test, compared with untreated control WT mice (Supplemental Figure 1). This finding supports the hypothesis that valsartan may benefit spatial memory reference deficits in Tg2576 mice selectively, through the attenuation of $\mathrm{AD}$-type $\mathrm{A} \beta$-mediated response in the brain. 
A

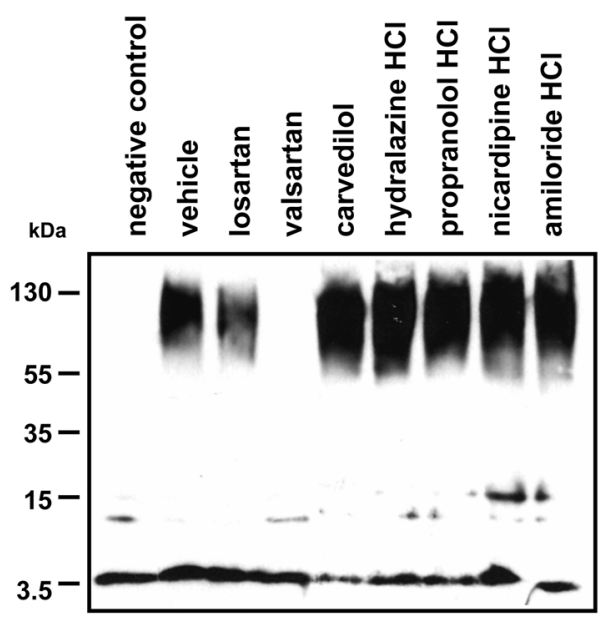

B

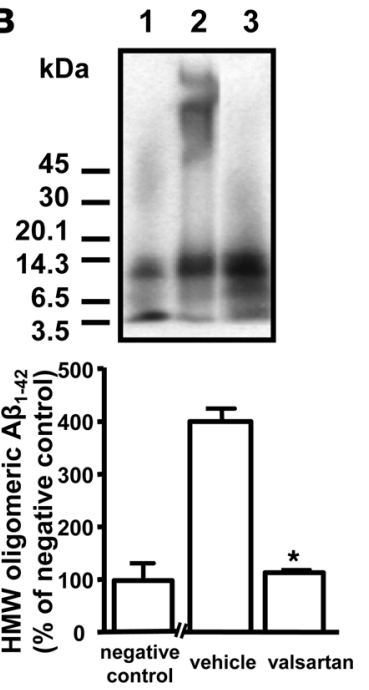

C
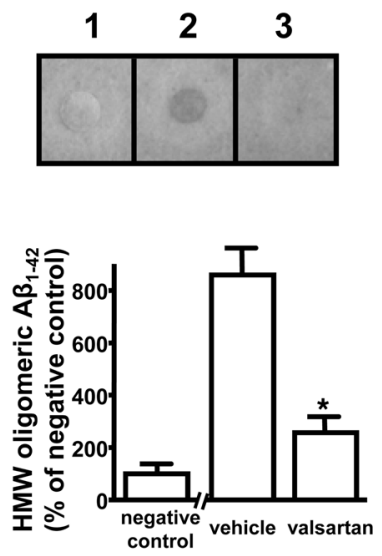

\section{Figure 1}

Valsartan prevents oligomerization of $A \beta_{1-42}$ peptide into a HMW $A \beta$ species in vitro. (A) Western blot analysis of $A \beta_{1-42}$ oligomers in the presence of losartan, valsartan, carvedilol, hydralazine, propranolol, nicardipine, or amiloride. Bands at $3.5 \mathrm{kDa}$ represent the monomeric $\mathrm{A} \beta$ form, whereas the smear between 55 and $130 \mathrm{kDa}$ represents the oligomeric form of $A \beta$. (B) Valsartan decreases the accumulation of HMW $A \beta_{1-42}$ species. Inset: Nonaggregated $A \beta_{1-42}$ control (lane 1). Representative Western immunoblot of $A \beta_{1-42}$ in the absence (lane 2 ) or presence of $10 \mu \mathrm{M}$ valsartan (lane 3). (C) Quantitative dot blot analysis of valsartan inhibition of $A \beta_{1-42}$ oligomerization. The same samples used in B were subjected to dot blot analysis using oligomer-specific antibody A11. Inset: Representative dot blot image. Results are expressed as percent of negative control (negative control presents nonaggregated $A \beta$ ), and values represent mean $\pm \mathrm{SEM}$. ${ }^{\star} P<0.05$.

Given the central role of soluble HMW extracellular A $\beta$ oligomers in $\mathrm{AD}$-type cognitive deterioration, we examined the accumulation of HMW A $\beta$ peptides in the brain. We found that treatment of Tg 2576 mice with valsartan, at either 10 or $40 \mathrm{mg} / \mathrm{kg} / \mathrm{d}$, resulted in an approximately 2 - to 3 -fold reduction in HMW A $\beta$ oligomers in the cerebral cortex (Figure 3B), approximately 5 months after treatment. This reduction in soluble HMW A $\beta$ oligomers in both 10 and $40 \mathrm{mg} / \mathrm{kg} / \mathrm{d}$ valsartan-treated animals coincided with improvement in spatial memory function in these animals. Besides the reduction in HMW oligomeric $A \beta$, we also found a significant reduction in total soluble $A \beta$ peptide in the valsartan-treated mouse brains (Figure 3C).

While it is possible that the observed reduction in soluble, extracellular HMW A $\beta$ oligomeric peptide content might be a reflection of an overall reduction in total $A \beta$ peptide (see below; Figure $3 \mathrm{D}$ ), we note that the ratio of soluble HMW A $\beta$ to total soluble A $\beta$ content in the brain of valsartan-treated Tg2576 was approximately 2 -fold lower than that in the untreated $\operatorname{Tg} 2576$ animals, tentatively suggesting that a significant proportion of the total soluble $A \beta$ peptides in the brain of the valsartan-treated groups is not in the neurotoxic soluble, extracellular HMW form. This evidence supports the potential role of valsartan as an inhibitor of $\mathrm{A} \beta$ oligomerization.

Valsartan prevents AD-type amyloid neuropathology. Treatment of $\mathrm{Tg} 2576$ mice with $40 \mathrm{mg} / \mathrm{kg} / \mathrm{d}$ valsartan resulted in a 1 - to 2 -fold reduction in total guanidine-extractable $\mathrm{A} \beta_{1-42}$ peptide $(P<0.05)$ and $A \beta_{1-40}$ peptide $(P<0.05)$ in the cerebral cortex and hippocampal formation $\left(P<0.05\right.$ and $P<0.01$ for $\mathrm{A} \beta_{1-42}$ and $\mathrm{A} \beta_{1-40}$, respectively) (Figure $3 \mathrm{D}$ ). We found that treatment with $10 \mathrm{mg} / \mathrm{kg} / \mathrm{d}$ valsartan also reduced total $A \beta_{1-40}$ peptide accumulation in the brain compared with the untreated control animals $(P<0.05$ for both cerebral cortex and hippocampal formation) (Figure 3D).
Finally, consistent with this evidence that valsartan treatment prevents the accumulation of total $A \beta$ peptides in the brain, we also found a significant reduction in AD-type amyloid plaque burden in the contralateral hemisphere of the same Tg2576 mice treated with valsartan at $10 \mathrm{mg} / \mathrm{kg} / \mathrm{d}(P<0.01$ for cortex; $P<0.05$ for hippocampus) or $40 \mathrm{mg} / \mathrm{kg} / \mathrm{d}(P<0.01$ for cortex; $P<0.05$ for hippocampus), relative to age- and sex-matched untreated control Tg2576 mice, as assessed stereologically (Figure 3E).

Valsartan may beneficially influence $A D$ pathogenesis through degradation and clearance of $A \beta$ from the brain. To understand the mechanisms underlying the benefits of valsartan on AD-type cognitive function and $A \beta$ neuropathology, we first examined whether valsartan can influence the processing of the APP. We found that valsartan treatment had no effect on APP holoprotein levels (C8 antibody that detects the full-length APP protein) in brain homogenates (cerebral cortex) (Figure 4A). Nor did $\alpha$-, $\beta$-, and $\gamma$-secretase activities in the cerebral cortex of valsartan-treated $\operatorname{Tg} 2576$ mice differ from those of age- and sex-matched untreated control Tg2576 mice (Figure 4B). In addition, we found no detectable change in the content of $\alpha-, \beta$-, or $\gamma$-carboxyterminal fragments ( $\alpha$-, $\beta$-, or $\gamma$-CTFs), in the brain of Tg 2576 mice treated with $10 \mathrm{mg} / \mathrm{kg} / \mathrm{d}$ or $40 \mathrm{mg} / \mathrm{kg} / \mathrm{d}$ relative to untreated control Tg2576 mice $(P=0.46, P=0.25$, and $P=0.23$ for $\alpha$-, $\beta$-, and $\gamma$-CTFs, respectively; 1-way ANOVA); similarly, no detectable changes were found in the content of soluble APP $\alpha(\operatorname{sAPP} \alpha)(P=0.45)$ or $\operatorname{sAPP} \beta(P=0.94)$ in the brain of valsartan-treated mice at either 10 or $40 \mathrm{mg} / \mathrm{kg} / \mathrm{d}$ relative to untreated control $\operatorname{Tg} 2576$ mice.

Collectively, this evidence tentatively excludes the possibility that valsartan treatment in Tg2576 mice may prevent AD-type cognitive deterioration and $\mathrm{AD}$-type neuropathology by reducing the generation of $A \beta$ peptides in the brain from APP processing, as we also found in vitro. We note that in in vitro studies using 
A

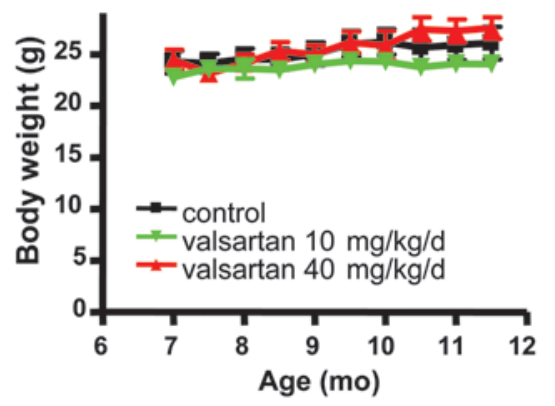

B

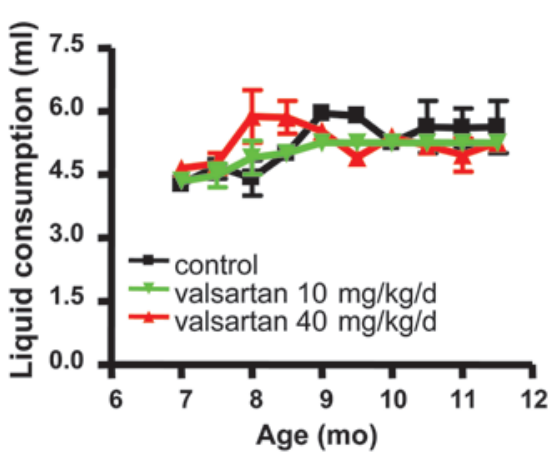

C

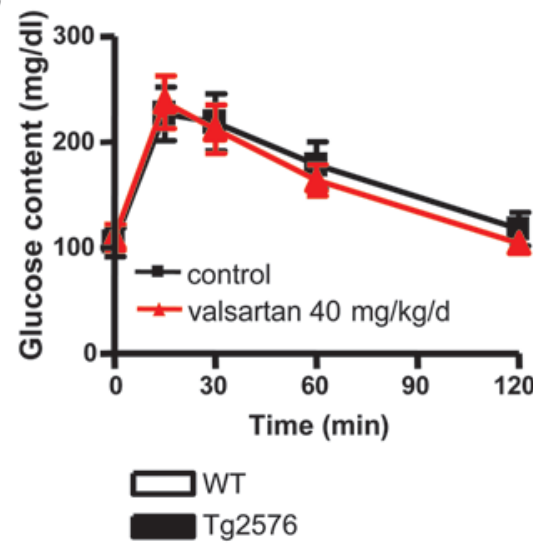

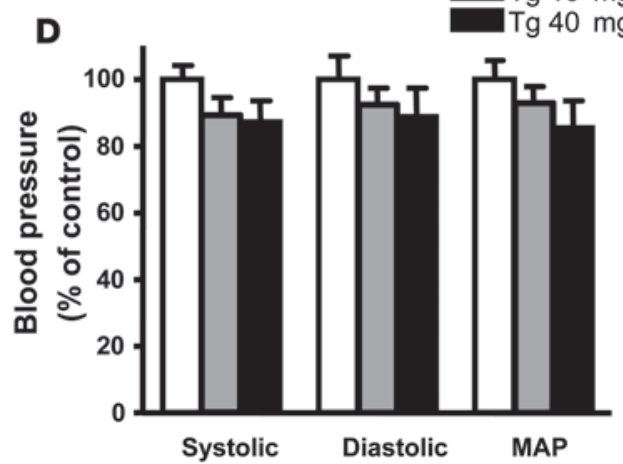

E

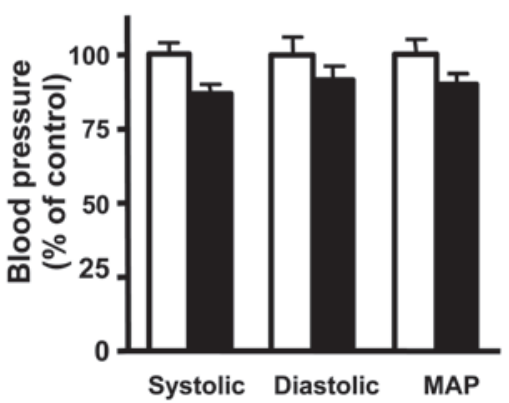

Figure 2

Chronic valsartan treatment is highly tolerable in Tg2576 mice. Valsartan was provided to female Tg2576 mice from 6 to 11.5 months of age at $10 \mathrm{mg} / \mathrm{kg} / \mathrm{d}$ or $40 \mathrm{mg} / \mathrm{kg} / \mathrm{d}$. (A and B) Body weight and fluid consumption were monitored weekly. (C) Postprandial glucose tolerance response was examined after 5 months of valsartan treatment. (D) Tg2576 blood pressure measurements in response to approximately 5 months of valsartan treatments. (E) Baseline measurements of systolic and diastolic blood pressure and mean arterial blood pressure (MAP) in adult female Tg2576 mice and strain-, age-, sex-matched WT mice. The blood pressure determination for each animal was calculated as the mean of 10 individual measurements. Values represents group mean values \pm SEM; $n=7-9$ mice per group.

primary $\operatorname{Tg} 2576$ neuron cultures, valsartan treatment had no influence on intracellular $\mathrm{A} \beta$ content, as assessed by Western blot analysis (data not shown).

Based on the valsartan-induced decrease in total $A \beta_{1-40}$ or $A \beta_{1-42}$ content in the brain, independent of mechanisms involving APP processing, we considered the possibility that valsartan treatment could lead to reduced levels of $A \beta$ peptides in the serum, thereby creating a "sink effect" that promotes efflux of $A \beta$ from the brain into the circulation (27). There was a $20 \%-25 \%$ dose-dependent reduction in $A \beta_{1-42}$ and $A \beta_{1-40}$ in the serum of valsartan-treated Tg2576 mice, relative to untreated controls (Figure 4C), but these changes did not reach statistical significance. It is still possible that valsartan treatment reduces the accumulation of $A \beta$ peptides, including soluble extracellular HMW A $\beta$ oligomers, in the brain, in part by promoting peripheral $\mathrm{A} \beta$ clearance.

While valsartan showed no influence on secretase activity or APP processing, we did find that valsartan treatment at $40 \mathrm{mg} / \mathrm{kg} / \mathrm{d}$ led to a significant elevation in the activity of cell membranebound (CM-bound) insulin-degrading enzyme (IDE) in the cerebral cortex $(P=0.0211)$ (Figure $4 \mathrm{D})$, accompanied by elevation of IDE protein content (Figure 4D, inset), relative to age- and sex-matched untreated control Tg2576 mice. This elevation of IDE in Tg2576 mice was highly selective, as we found no detectable changes in intracellular soluble IDE (Figure 4D), neprilysin (Figure 4E), or endothelin-converting enzyme-1 (ECE-1) (Figure 4F) in the brains of valsartan-treated Tg2576 mice, relative to age- and sex-matched $\operatorname{Tg} 2576$ untreated control mice.

The upregulation of IDE activity in vivo is consistent with our in vitro finding in cortico-hippocampal primary neuron cultures derived from $\mathrm{Tg} 2576$ embryos. We found that cotreatment of cultures with the IDE inhibitor 1,10-phenanthroline prevented valsartan-mediated $A \beta_{1-42}$-lowering activities in the conditioned medium 16 hours after treatment; $A \beta_{1-42}$ content in the conditioned medium as percentage of control cultures: vehicle-treated cultures, $100 \% \pm 2.45 \%$; valsartan-treated $(50 \mu \mathrm{M})$ neuron cultures, $49.2 \% \pm 4.7 \%$ ( $P<0.001$ vs. control); valsartan plus 1,10 -phenanthroline-treated $(60 \mu \mathrm{M})$ cultures, $96.0 \% \pm 2.24 \%(P<0.001$ vs. valsartan alone; 1 -way ANOVA followed by Newman-Keuls post-hoc analysis). Collectively, this evidence supports the central role of IDE in modulating A $\beta$ lowering activities in response to valsartan treatment in the brain.

Based on recent evidence showing that $\mathrm{AD}$ dementia is associated with reduced membrane IDE activity and content, but not soluble IDE (28), our observation suggests that valsartan treatment might reduce total $A \beta$ content, including HMW soluble $A \beta$ in the brain, in part, by facilitating membrane-associated IDE-mediated proteolytic cleavage of $A \beta$ peptides.

\section{Discussion}

This study was designed primarily in response to a series of epidemiological and clinical studies reporting mixed results on the 
A

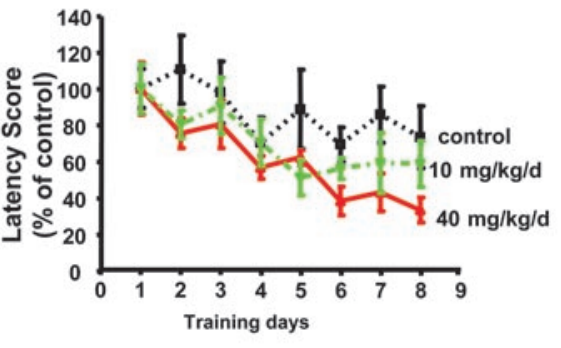

D

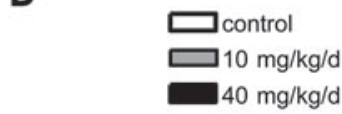

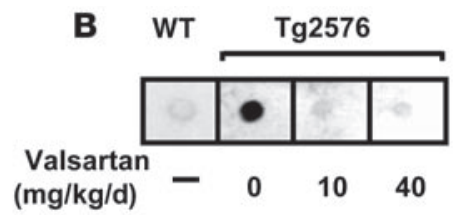
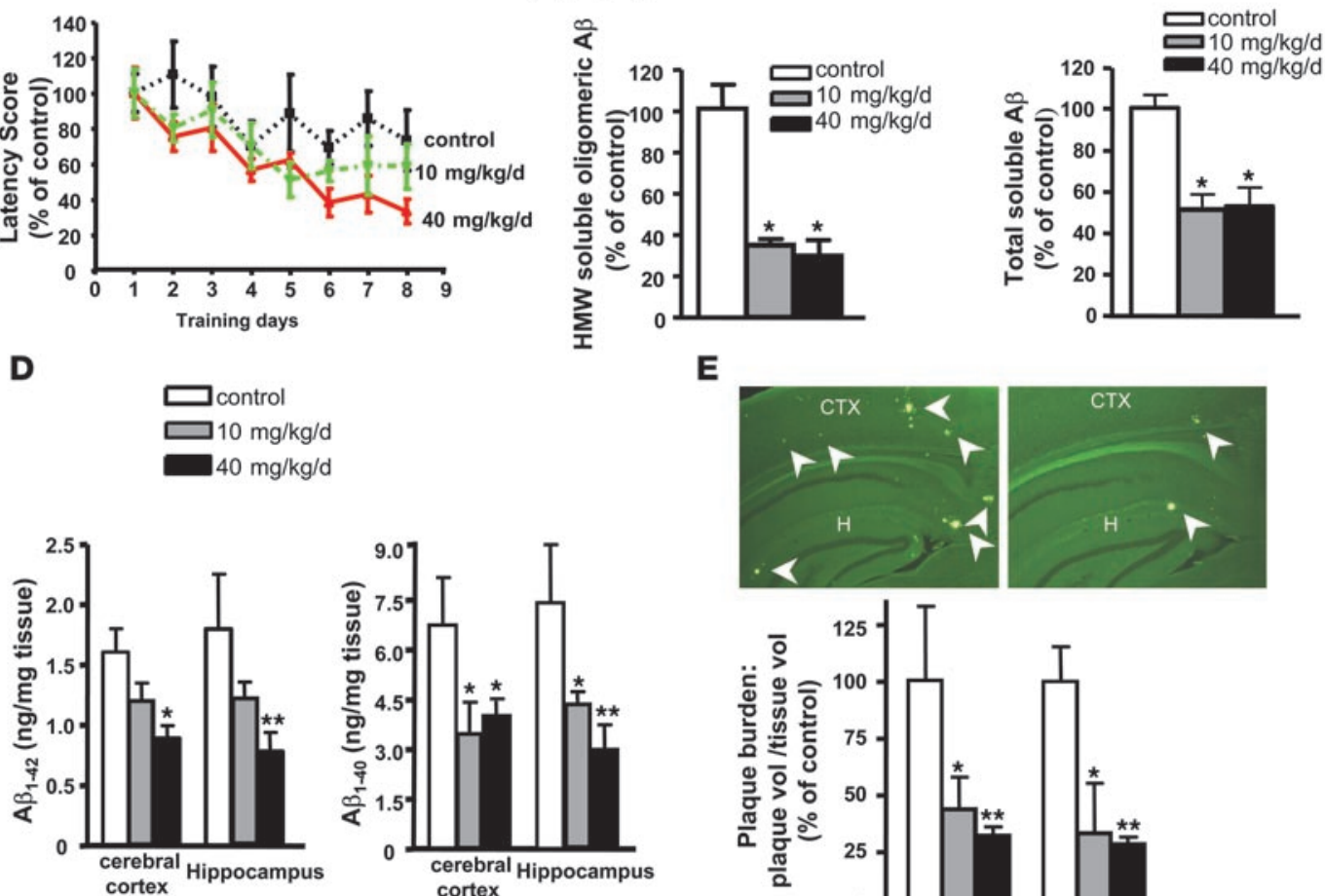

E
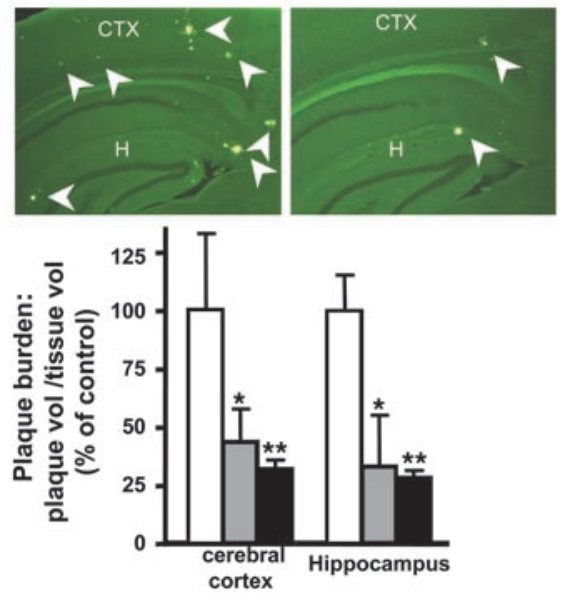

Figure 3

Chronic valsartan treatment of Tg2576 mice resulted in dose-dependent attenuations of AD-type spatial memory deterioration in Tg2576 mice, which is coincidental with significant reductions in HMW soluble A $\beta$ species and AD-type neuropathology in the brains of Tg2576 mice. (A) The influence of $A \beta$-related spatial memory in response to valsartan treatment at 10 and $40 \mathrm{mg} / \mathrm{kg} / \mathrm{d}$ versus the untreated control Tg2576 mice was assessed using an MWM test in approximately 11-month-old female Tg2576 mice. Latency score represents time taken to escape to the platform from the water. (B) Assessments of soluble, extracellular HMW A $\beta$ peptide contents in the brain using an antibody specific for HMW oligomeric $A \beta$ peptides in a dot blot analysis. Inset: Representative dot blot analysis of HMW soluble A $\beta$ contents. (C) Assessment of total PBSsoluble $A \beta$ peptide using ELISA assay. (D) Assessment of $A \beta_{1-42}$ and $A \beta_{1-40}$ peptide concentrations in the cerebral cortex and hippocampus of valsartan-treated (10 or $40 \mathrm{mg} / \mathrm{kg} / \mathrm{d}$ ) or control mice. (E) Stereological assessment of cerebral cortex and hippocampal A $\beta$ plaque burden in valsartan-treated or control mice expressed as thioflavin-S-positive volume as a percentage of regional volume. Inset: Representative photograph of thioflavin-S-positive A $\beta$ plaque neuropathology in neocortex (CTX) and hippocampal formation (H) in untreated control (left panel) and valsartan-treated $(40 \mathrm{mg} / \mathrm{kg} / \mathrm{d}) \mathrm{Tg} 2576$ mice (right panel). Arrowheads point toward thioflavin-S positive amyloid plaques. Original magnification, $\times 125$. Values represent group mean \pm SEM; $n=7-9$ mice per group. In $\mathbf{B}$ and $\mathbf{C},{ }^{*} P<0.001$; In $\mathbf{D}$ and $\mathbf{E},{ }^{*} P<0.05$, ${ }^{* \star} P<0.01 ; 1$-way ANOVA followed by Newman-Keuls post-hoc analysis.

association of the use of antihypertensive drugs and $\mathrm{AD}$ incidence (1-5). To clarify whether any of the currently available antihypertensive medications could provide beneficial AD-modifying activity, we surveyed 55 antihypertensive drugs for their potential beneficial role in AD-type amyloid neuropathology. Seven of these were identified to significantly reduce $A \beta$ accumulation in vitro. Among these 7 drugs tested for antioligomerization activity, we found valsartan, and to a lesser extent losartan, to be the only drugs capable of attenuating oligomerization of $A \beta$ peptides into soluble HMW oligomeric $\mathrm{A} \beta$ species in vitro.

Valsartan treatment prevents $A \beta$-related spatial memory reference deficits and $\mathrm{AD}$-type neuropathology in vivo at doses equivalent to or lower than the recommended dose for humans. In our study we found that treatment of $\mathrm{Tg} 2576$ mice with valsartan at a concentration as low as $10 \mathrm{mg} / \mathrm{kg} / \mathrm{d}$ attenuated spatial reference memory deterioration that coincided with an approximately 3 -fold reduction in HMW A $\beta$ peptide content in the brain, while IDE activity and the content of total $A \beta_{1-42}$ (but not total $A \beta_{1-40}$ ) were unaffected. We hypothesize that treatment with the low valsartan dose most likely beneficially influences AD-type spatial memory deterioration through direct interaction of valsartan with $A \beta$ peptides in the brain (as we found in vitro) and prevents the generation of soluble, extracellular HMW A $\beta$ species. This activity is independent of IDE promotion. This scenario is consistent with the recent study showing that extracellular, soluble HMW oligomeric $A \beta$ peptides purified from the brain of middle-aged, impaired Tg2576 mice could disrupt memory functions, even episodically, when administered to 

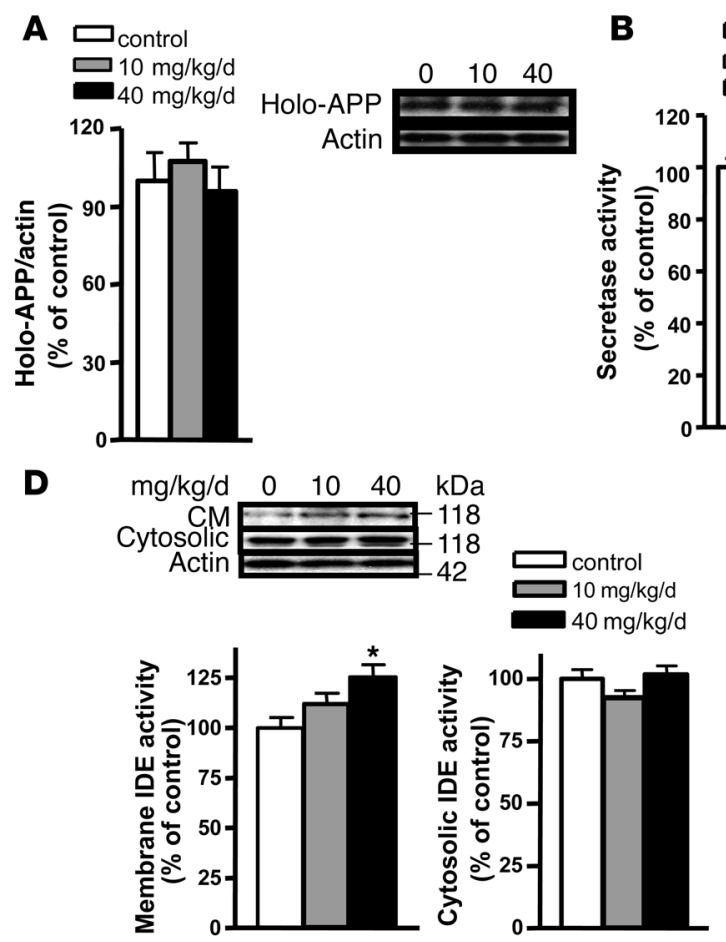

$\square$ control

$10 \mathrm{mg} / \mathrm{kg} / \mathrm{d}$

$40 \mathrm{mg} / \mathrm{kg} / \mathrm{d}$

7
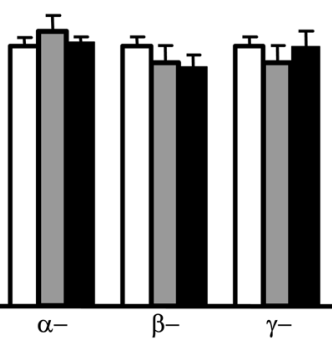

E $\quad \mathrm{mg} / \mathrm{kg} / \mathrm{d} \quad 0 \quad 10 \quad 40$

Neprilysin $=-$
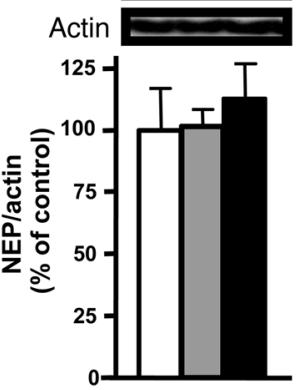

C
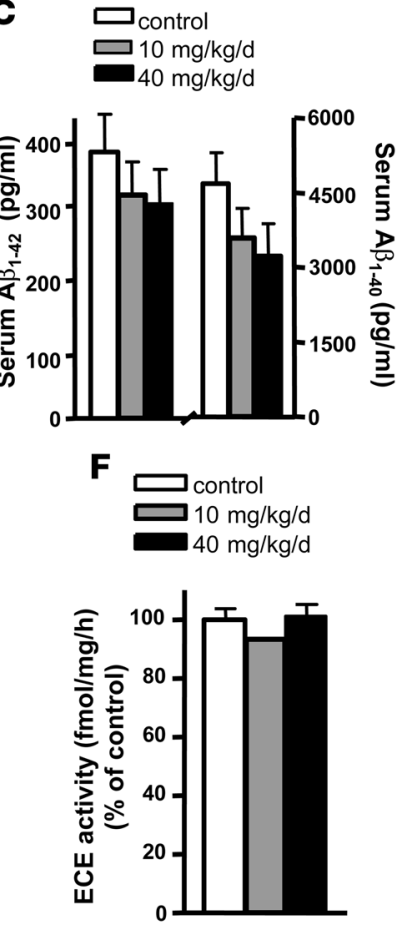

Figure 4

Valsartan treatments prevented cognitive impairment and attenuate AD-type neuropathology, in part, by promoting membrane-bound insulin degradation enzyme activity. (A) APP content in the cortex of valsartan-treated or untreated control Tg2576 mice. Inset: Representative immunoreactive APP (C8 antibody) and $\beta$-actin signals. (B) Assessments of cellular $\alpha-, \beta-$, and $\gamma$-secretase activities in the cerebral cortex of Tg2576 mice in response to valsartan treatment. (C) Assessment of $A \beta_{1-42}$ and $A \beta_{1-40}$ peptide content in peripheral blood (serum). (D) Assessments of CM-associated (left panel) and cytosolic (right panel) IDE activity in the cerebral cortex of Tg2576 mice in response to valsartan treatment. Inset: Representative immunoblot signals of membrane and cytosolic IDE protein content from the same samples. (E) Assessments of neprilysin content by Western blotting using a commercial rabbit anti-mouse neprilysin antibody. Inset: Representative neprilysin and actin protein signals from the same blot. (F) Assessment of ECE activity using an Endothelin-1 ELISA System. Values represent group mean \pm SEM; $n=7-9$ mice per group. ${ }^{*} P<0.05$; 1 -way ANOVA, followed by Newman-Keuls post-hoc analysis.

normal rats (18). In addition to preventing $A \beta$ oligomerization, we found that the higher dose of valsartan $(40 \mathrm{mg} / \mathrm{kg} / \mathrm{d})$ also significantly promoted CM-IDE activity in the cerebral cortex of Tg2576 mice. This increase in CM-IDE activity was highly selective, as there was no detectable change in other proteases involved in the clearance of $A \beta$ (e.g., neprilysin and ECE). Thus at the higher dose, valsartan most likely benefited spatial memory functions in $\operatorname{Tg} 2576$ mice by simultaneously increasing A $\beta$ degradation by IDE and reducing $A \beta$ aggregation into soluble, extracellular HMW A $\beta$ species.

Finally, an additional mechanism through which valsartan prevents $A \beta$-related spatial memory impairment and $A D$-type neuropathology may be through the promotion of $A \beta$ "sinking" from the brain to the periphery, as suggested by the decreased level of serum A $\beta$ in valsartan-treated Tg2576 mice. However, our results did not reach statistical significance. Additional studies will clarify whether valsartan treatment may also reduce $A \beta$ neuropathology by promoting $A \beta$ sinking from the brain to the periphery.

Collectively, our evidence suggests that valsartan treatment might prevent $A \beta$-related spatial memory reference deficits in the $\mathrm{Tg} 2576 \mathrm{AD}$ mouse model through a combination of multiple mechanisms: (a) reducing $A \beta$ aggregation into HMW A $\beta$ species; (b) increasing $A \beta$ degradation by IDE; and possibly (c) promoting sinking of $A \beta$ peptides from the brain to the periphery.
Valsartan beneficially prevented $A \beta$-related spatial memory reference deficit in $\operatorname{Tg} 2576$ mice at a dose less than the equivalent recommended clinical dose for hypertensive treatment. While there are as yet no data in humans to support the idea that angiotensin receptor-blocking drug valsartan has any impact on the incidence or progression of cognitive impairment, this study may provide the appropriate impetus for clinical trials in vulnerable human subjects, such as patients with mild cognitive impairment, at subclinical doses.

Aside from valsartan, we identified 6 antihypertensive drugs that significantly reduced accumulations of $A \beta$ peptides in vitro in primary $\operatorname{Tg} 2576$ cortico-hippocampal neuron cultures. While our evidence supports the in vivo efficacy of valsartan to attenuate $\mathrm{AD}$-type phenotypes in Tg2576 AD mouse model, we have not yet determined the in vivo efficacy of the other 6 A $\beta$-lowering antihypertensive drugs. Many factors, including biological availability and drug metabolism, may influence $A \beta$ lowering activity of a drug in vivo. It would not be surprising if some drugs that are biologically active in vitro were not effective in vivo. Thus, individual drugs must be investigated on a caseby-case basis. Ongoing studies in our laboratory are evaluating the remaining 6 antihypertensives individually for their in vivo efficacy to protect against progressive $A \beta$ neuropathology and $\mathrm{A} \beta$-related memory deficits in AD. 


\section{Methods}

Cell cultures and drug screening. E16 cortico-hippocampal neuronal cultures were prepared from heterozygous Tg2576 transgenic mice (Tg2576 neurons) (20) (see below). Embryonic brain tissue was mechanically triturated and centrifuged. Neurons were seeded onto poly-D-lysine-coated 96-well plates at $1.0 \times 10^{5}$ cells per well and cultured in the serum-free chemically defined Neurobasal medium, supplemented with $2 \%$ B27, $0.5 \mathrm{mM}$ L-glutamine, and $1 \%$ penicillin-streptomycin (Gibco-BRL; Invitrogen). The absence of astrocytes $(<2 \%)$ was confirmed by the virtual absence of glial fibrillary acidic (GFAP) protein immunostaining (data not shown). For primary screening, cultured neurons were treated with $100 \mu \mathrm{M}$ of drug in duplicate for 16 hours; all drugs were obtained in stock from MicroSource Discovery Systems Inc. Conditioned medium was collected for A $\beta$ detection using commercially available ELISA kits (BioSource). Drugs that reduced $A \beta$ content by more than $15 \%$ in the primary screening were selected for secondary screening. Primary neurons prepared in 96-well plates were treated with $0.1 \mu \mathrm{M}, 1 \mu \mathrm{M}, 10 \mu \mathrm{M}, 50 \mu \mathrm{M}$, and $100 \mu \mathrm{M}$ of each drug in duplicate for approximately 16 hours, and conditioned medium was collected for $A \beta$ detection. Cell viability was assessed using a commercial available $\mathrm{LDH}$ assay kit according to the manufacturer's instruction (Promega). The $\mathrm{EC}_{50}$ value of each drug was calculated using the GraphPad Prism software package (GraphPad Software).

$A \beta$ peptide oligomerization assay in vitro. Lyophilized $A \beta_{1-42}$ peptide was dissolved in 1,1,1,3,3,3,-hexafluoro-2-propanol (HFIP; Sigma-Aldrich), incubated at room temperature for 60 minutes, aliquoted, vacuum dried, and stored at $-80^{\circ} \mathrm{C}$. A $\beta$ peptide was dissolved in DMSO and diluted into $\mathrm{ddH}_{2} \mathrm{O}$ to a final concentration of $100 \mu \mathrm{g} / \mathrm{ml}$. The peptide was then mixed with equal volume of drugs and incubated at $37^{\circ} \mathrm{C}$ for 1 day (29).

Following incubation, samples were centrifuged at $14,000 \mathrm{~g}$ for 10 minutes at $4{ }^{\circ} \mathrm{C}$. Supernatants were mixed with $2 \times$ SDS sample buffer and separated on a $10 \%-20 \%$ Tris-Tricine gradient SDS gel (Invitrogen). The separated peptides were subjected to Western blotting using 6E10 antibody (1:1,000; Signet). Immunoreactive signals were visualized using ECL detection (Amersham) and quantified densitometrically (Quantity One; Bio-Rad).

For dot blot analysis, samples used for the Western blot analysis (100 ng peptide) were directly applied to the nitrocellulose membrane, air dried, and blocked with $5 \%$ nonfat milk followed by incubation with antibody A11 (Biosource), an antibody that specifically recognizes the oligomeric form of $A \beta$. Immunoreactive signals were detected and quantified as described above.

Tg2576 mice and valsartan treatment. This study used Tg2576 AD transgenic mice that express the human 695-aa isoform of APP containing the Swedish double mutation $\left(\mathrm{APP}_{\text {swe }}\right.$ ) [(APP695)Lys670 $\rightarrow$ Asn, Met671 $\rightarrow$ Leu] driven by a hamster prior promoter. Female Tg2576 mice and age-, sex-, and strain-matched WT mice (Taconic) were randomly assigned to the following valsartan treatment groups: $10 \mathrm{mg} / \mathrm{kg} / \mathrm{d}, 40 \mathrm{mg} / \mathrm{kg} / \mathrm{d}$, and the control water treatment group. In the Tg2576 AD mouse model, $\mathrm{A} \beta$ peptide content in the brain accumulates exponentially between 7 and 12 months of age $(24,30)$; therefore, we treated animals for 5 months, starting at 6 months of age. All animal studies were approved by the Institutional Animal Care and Use Committee of Mount Sinai School of Medicine.

Valsartan monosodium salt was obtained from MicroSource Discovery Systems Inc. For the preparation of valsartan drinking solutions, we dissolved valsartan (stored in a dry environment) in sterile water by adding valsartan salt to water at $30-40^{\circ} \mathrm{C}$ and stirred vigorously until it was completely dissolved. The solution was then cooled to room temperature slowly without external cooling to discourage precipitation of the drug. Valsartan salt has a solubility of approximately $5 \mathrm{~g} / \mathrm{l}$ at room temperature, and the aqueous valsartan salt solution is slightly acidic, with a $\mathrm{pH}$ of 5.5. We generally neutralize aqueous valsartan solution with sodium bicarbon- ate without detectable reduction of valsartan solubility. For our preclinical in vivo studies, we prepared neutralized valsartan aqueous solutions at concentrations $(50-200 \mathrm{mg} / \mathrm{l})$ well below the maximal solubility of sodium valsartan in water. Valsartan solutions in the drinking water were wrapped in aluminum to avoid potential photochemical changes and always maintained at room temperature to avoid potential precipitation from solution. Valsartan salt does not contain labile groups, and routine quality control checking detected no change in the recovered compound on TLC analysis at both 50 and $200 \mathrm{mg} / \mathrm{l}$ valsartan solutions. Quality was assessed in 3- to 10-week-old solutions stored at room temperature in dark compartments (data not shown). Drinking solutions for the in vivo treatments were freshly prepared twice a week. Liquid consumption and animal body weight were monitored weekly throughout the study.

At approximately 11 months of age, following assessment of spatial memory functions by the MWM test, mice were anesthetized with the general inhalation anesthetic 1-chloro-2,2,2-trifluoroethyl difluoromethyl ether (Baxter Healthcare) and sacrificed by decapitation. Brains were harvested and hemi-dissected. One hemisphere was fixed in $4 \%$ paraformaldehyde for 24 hours for histological studies. Hippocampus and cortex were dissected from the opposite hemisphere, rapidly frozen, pulverized in liquid nitrogen, and stored at $-80^{\circ} \mathrm{C}$ for biochemical studies.

Assessment of blood pressure and glucose utilization. Mouse blood pressure was routinely recorded using a commercial blood pressure analysis system designed specifically for small rodents (Hatteras Instruments). To assess potential alteration in glucose utilization in response to chronic treatment with valsartan, we used an insulin glucose tolerance test (IGTT), as previously described (31). Briefly, mice were given a single dose of glucose postprandially (i.p. $2 \mathrm{~g} / \mathrm{kg}$ body weight). Blood was collected from the tail vein periodically over a 2 -hour period. Blood glycemic content was assessed using the OneTouch LifeScan System (LifeScan), following the manufacturer's instructions.

Behavioral assessment of cognitive function by the MWM test. We used the MWM test to evaluate working and reference memory function in response to treatment with valsartan in $\mathrm{Tg} 2576$ mice, as previously described (25). At approximately 11 months of age, mice were put into the water maze from 4 different quadrants; spatial memory was assessed by recording the average latency time for the animal to escape to the hidden platform. The behavior analysis was consistently conducted during the last 4 hours of the day portion of the light cycle in an environment with minimal stimuli (e.g., noise, movement, or changes in light or temperature).

Assessment of $H M W$ soluble oligomeric A $\beta$ oligomerization in the brain by dot blot assay. In this study, soluble proteins were extracted from the brain samples (cortex) with PBS in the presence of protease inhibitors and centrifuged at 78,500 $\mathrm{g}$ for 1 hour at $4^{\circ} \mathrm{C}(32)$. Four micrograms of extracellular soluble protein isolated from the cerebral cortex of valsartan- or vehicle-treated $\operatorname{Tg} 2576$ mice was directly applied to a nitrocellulose membrane, air dried, and blocked with $5 \%$ nonfat milk, as previously described (21). The membrane was probed with either anti-oligomer A11 antibody (1:1,000; Biosource) or 6E10 antibody (1:1,000; Signet) (21). Dot blot immunoreactivities were quantified densitometrically. For total soluble $A \beta$ assessment, the extracellular soluble protein used for dot blot was subject to ELISA analysis (BioSource) (21).

Assessment of AD-type amyloid neuropathology in Tg2576 mice. For quantitative assessment of $A \beta$ peptide in the brain, frozen pulverized tissue was homogenized in 5.0 M guanidine buffer, diluted (1:10) in PBS containing $0.05 \%$ (vol/vol) Tween-20 and $1 \mathrm{mM}$ Pefabloc protease inhibitors (Roche Biochemicals) and centrifuged for 20 minutes at $4^{\circ} \mathrm{C}$. Total $A \beta_{1-40}$ or $A \beta_{1-42}$ was quantified by sandwich ELISA (BioSource), as previously reported (29). Serum A $\beta$ content was analyzed using the same ELISA kit, following manufacturer's instructions. 
For stereological assessment of AD-type amyloid burden, freshly harvested mouse brain hemispheres were immersion fixed overnight in $4 \%$ paraformaldehyde. They were then sectioned in the coronal plane on a Vibratome at a nominal thickness of $50 \mu \mathrm{m}$. Every 12th section was selected from a random start position and processed for thioflavin-S staining, as previously described $(29,33)$. All stereologic analysis was performed using a Zeiss Axiophoto photomicroscope equipped with a Zeiss motorized stage and MSP65 stage controller, a high-resolution MicroFire digital camera, and a Dell computer running the custom-designed software Stereo Investigate (MBF Bioscience). The amyloid burden was estimated using the Cavalieri principle with a small-size grid $(25 \times 25 \mu \mathrm{m})$ for point counting, as previously described (29).

APP processing and $\alpha$-, $\beta$-, $\gamma$-secretase activity. Expression of holo-APP was examined by Western blot analysis with the $\mathrm{C} 8$ antibody (raised against aa 676-695 of human APP cytoplasmic domain; gift of Dennis Selkoe, Brigham and Women's Hospital, Boston, Massachusetts, USA). Immunoprecipitation was performed for detection of sAPP $\alpha$ and $\mathrm{SAPP} \beta$ as previously described (29). $\alpha$-, $\beta$-, and $\gamma$ - CTFs were assessed by Western blot analysis as previously described (29). $\alpha$-, $\beta$-, and $\gamma$ - secretase activities were assessed using commercially available kits (R\&D Systems) $(29,34)$. Brain samples were homogenized in supplied buffers. Homogenate was then added to secretase-specific APP peptide conjugated to the reporter molecules EDANS and DABCYL. In the uncleaved form, fluorescent emissions from EDANS were quenched by the physical proximity of the DABCYL moiety. Cleavage of APP peptide by secretase physically separates the EDANS and DABCYL reporter molecules, allowing for the release of a fluorescent signal. The level of secretase enzymatic activity is proportional to the fluorometric reaction in the homogenate (R\&D Systems).

IDE protein content and enzymatic activity assay. Frozen brain samples were pulverized in dry ice and homogenized in homogenization buffer $(50 \mathrm{mM}$ HEPES pH 7.4, $100 \mathrm{mM} \mathrm{NaCl}, 20 \mu \mathrm{l}$ Sigma Protease Inhibitor/ml tissue homogenate by passing them through a 26 -gauge needle approximately 15 times. Lysates were first centrifuged at $2,500 \mathrm{~g}, 15$ minutes at $4^{\circ} \mathrm{C}$, to remove nuclei and cell debris and subsequently at $100,000 \mathrm{~g}$ at $4^{\circ} \mathrm{C}$ for 60 minutes, to separate the postnuclear membrane fraction (pellet) and cytosolic fraction (supernatant) (35). Fractions were then separated (25-30 $\mu$ g proteins) on $10 \%$ SDS-PAGE and subjected to Western blot analysis using rabbit antimouse IDE antibody (Abcam Inc.). IDE immunoreactivity was visualized with ECL (Amersham) and quantified densitometrically. Actin immunoreactivities (rabbit anti-actin; 1:5,000; Sigma-Aldrich) were used to control sample loading and normalization of IDE immunoreactive signal.

IDE activity was measured by degradation of [125I]insulin, as previously described, with modifications $(35,36)$. Briefly, the same protein fractions $(50 \mu \mathrm{g})$ used for assessment of IDE protein expression were incubated in the presence of [125I] insulin in reaction buffer $(50 \mathrm{mM}$ HEPES pH 7.4, $100 \mathrm{mM} \mathrm{NaCl}, 20 \mu$ l Sigma Protease Inhibitor/ml tissue homogenate, and $1 \% \mathrm{BSA}$ ) at $37^{\circ} \mathrm{C}$; the reaction was stopped by adding 9 volumes of $5 \%$ TCA. The levels of [ $\left.{ }^{125} \mathrm{I}\right]$ insulin released into the TCAsoluble, degraded insulin or TCA-insoluble, undegraded insulin were used as IDE activity indexes.

ECE activity and neprilysin protein content. Frozen pulverized brain samples were homogenized in homogenization buffer $(50 \mathrm{mM}$ Tris/pH 6.8, $0.1 \mathrm{mM}$ PMSF); nuclei and cell debris were removed by centrifugation at $2,500 \mathrm{~g}$ for 15 minutes. The membrane pellet was obtained by centrifugation at $100,000 \mathrm{~g}$ for 45 minutes. The obtained membranes were washed once and dissolved in the homogenization buffer supplied with $1 \%$ $\mathrm{N}$-octyl-glucoside (Sigma-Aldrich) for 1 hour at $4{ }^{\circ} \mathrm{C}$. The nonsoluble part was removed by centrifugation at $20,000 \mathrm{~g}$ for 60 minutes. Protein content in the supernatant was measured using a Bio-Rad Protein Assay. Fifty micrograms of the membrane protein was incubated with $100 \mathrm{ng}$ rat big ET-1 (American Peptide Co.) at $37^{\circ} \mathrm{C}$ for 4 hours in $250 \mu \mathrm{l}$ of the reaction mixture $(50 \mathrm{mM}$ Tris/pH 7). The reaction was stopped by adding $600 \mu \mathrm{l}$ of cold ethanol $\left(-20^{\circ} \mathrm{C}\right)$. After centrifugation at $10,000 \mathrm{~g}$ for 10 minutes, the resulting supernatant was lyophilized, and the dry pellet was reconstituted with $250 \mu \mathrm{l}$ of the assay buffer and subjected to the ET-1 measurement by an Endothelin-1 Biotrak ELISA System (Amersham Biosciences). A cubic-spline curve was fitted to the standards, and the unknown values were interpolated from the standard curve $(37,38)$ (data not shown).

Zinc-dependent metalloprotease neprilysin content in the mouse brain was measured by Western blot analysis using rabbit anti-mouse NEP antibody (Alpha Diagnostics International).

Statistics. All values are expressed as mean \pm SEM. Differences between means were analyzed using either 2-way repeated measures ANOVA or ordinary 1-way ANOVA followed by Newman-Keuls post-hoc analysis, when indicated. In all analyses, the null hypothesis was rejected when $P$ was less than 0.05 . All statistical analyses were performed using the Prism Stat program (GraphPad Software Inc.).

\section{Acknowledgments}

This work was supported by the Altschul Foundation; the James J. Peters VA Geriatrics, Research, Education and Clinical Center Program; and National Institute on Aging grant AG02219 to G.M. Pasinetti.

Received for publication January 18, 2007, and accepted in revised form August 28, 2007.

Address correspondence to: Giulio Maria Pasinetti, Icahn Research Institute, Mount Sinai School of Medicine, 1425 Madison Avenue, Box 1230, New York, New York 10029, USA. Phone: (212) 659-8716 or (212) 659-8740; Fax: (212) 876-9042; E-mail: giulio.pasinetti@mssm.edu.
1. Lopez-Arrieta, J.M., and Birks, J. 2002. Nimodipine for primary degenerative, mixed and vascular dementia. Cochrane Database Syst. Rev. 3:CD000147.

2. Khachaturian, A.S., et al. 2006. Antihypertensive medication use and incident Alzheimer disease: the Cache County study. Arch. Neurol. 63:686-692.

3. Guo, Z.C., Viitanen, M., Winblad, B., and Fratiglioni, L. 1999. Low blood pressure and incidence of dementia in a very old sample: dependent on initial cognition. J. Am. Geriatr. Soc. 47:723-726.

4. Forette, F., et al. 2002. The prevention of dementia with antihypertensive treatment: new evidence from the Systolic Hypertension in Europe (SystEur) study. Arch. Intern. Med. 162:2046-2052.

5. in't Veld, B.A., Ruitenberg, A., Hofman, A., Stricker, B.H., and Breteler, M.M. 2000. Antihypertensive drugs and incidence of dementia: the Rotterdam study. Neurobiol. Aging. 54:A397.

6. Singer, R.B. 1991. Stroke in the elderly treated for systolic hypertension (SHEP). J. Insur. Med. 23:265-269.

7. Prince, M.J., Bird, A.S., Blizard, R.A., and Mann, A.H. 1996. Is the cognitive function of older patients affected by antihypertensive treatment? Results from 54 months of the Medical Research Council's treatment trial of hypertension in older adults. BMJ. 312:801-805

8. Lithell, H., et al. 2004. The Study on Cognition and Prognosis in the Elderly (SCOPE); outcomes in patients not receiving add-on therapy after randomization. J. Hypertens. 22:1605-1612.

9. Selkoe, D.J. 2001. Alzheimer's disease: genes, proteins, and therapy. Physiol. Rev. 81:741-766.

10. Busciglio, J., Gabuzda, D.H., Matsudaira, P., and Yankner, B.A. 1993. Generation of beta-amyloid in the secretory pathway in neuronal and nonneuronal cells. Proc. Natl. Acad. Sci. U. S. A. 90:2092-2096.

11. Haass, C., et al. 1992. Amyloid beta-peptide is produced by cultured cells during normal metabolism. Nature. 359:322-325.

12. Shoji, M., et al. 1992. Production of the Alzheimer amyloid-beta protein by normal proteolytic processing. Science. 258:126-129.

13. Esch, F.S., et al. 1990. Cleavage of amyloid-beta peptide during constitutive processing of its precursor. Science. 248:1122-1124.

14. Walsh, D.M., et al. 2002. Naturally secreted oligomers of amyloid beta protein potently inhibit hippocampal long-term potentiation in vivo. Nature. 416:535-539.

15. Lesne, S., et al. 2006. A specific amyloid-beta protein assembly in the brain impairs memory. Nature. 
440:352-357.

16. Kotilinek, L.A., et al. 2002. Reversible memory loss in a mouse transgenic model of Alzheimer's disease. J. Neurosci. 22:6331-6335.

17. Jacobsen, J.S., et al. 2006. Early-onset behavioral and synaptic deficits in a mouse model of Alzheimer's disease. Proc. Natl. Acad. Sci. U. S. A 103:5161-5166.

18. Cleary, J.P., et al. 2005. Natural oligomers of the amyloid-[beta] protein specifically disrupt cognitive function. Nat. Neurosci. 8:79-84.

19. Klyubin, I., et al. 2005. Amyloid beta protein immunotherapy neutralizes A beta oligomers that disrupt synaptic plasticity in vivo. Nat. Med. 11:556-561.

20. Mirjany, M., Ho, L., and Pasinetti, G.M. 2002. Role of cyclooxygenase- 2 in neuronal cell cycle activity and glutamate-mediated excitotoxicity. J. Pharmacol. Exp. Ther. 301:494-500.

21. Klein, W.L. 2002. Abeta toxicity in Alzheimer's disease: globular oligomers (ADDLs) as new vaccine and drug targets. Neurochem. Int. 41:345-352.

22. McLaurin, J., et al. 2002. Therapeutically effective antibodies against amyloid-[beta] peptide target amyloid-[beta] residues 4-10 and inhibit cytotoxicity and fibrillogenesis. Nat. Med. 8:1263-1269.

23. Yamamoto, S., et al. 1997. Pharmacological profile of valsartan, a non-peptide angiotensin II type 1 receptor antagonist -1 st communication: antihypertensive effects of valsartan in hypertensive models. Arzneimittelforschung. 47:604-612.

24. PDR.net. http://www.pdr.net.

25. Hsiao, K., et al. 1996. Correlative memory deficits, Abeta elevation, and amyloid plaques in transgenic mice. Science. 274:99-102.

26. Morris, R. 1984. Developments of a water-maze procedure for studying spatial learning in the rat. J. Neurosci. Methods. 11:47-60.

27. Morgan, D. 2005. Mechanisms of A beta plaque clearance following passive A beta immunization. Neurodegener. Dis. 2:261-266.

28. Zhao, Z., et al. 2007. Insulin degrading enzyme activity selectively decreases in the hippocampal formation of cases at high risk to develop Alzheimer's disease. Neurobiol. Aging. 28:824-830.

29. Wang, J., et al. 2005. Caloric restriction attenuates beta-amyloid neuropathology in a mouse model of Alzheimer's disease. FASEB J. 19:659-661.

30. Kawarabayashi, T., et al. 2001. Age-dependent changes in brain, CSF, and plasma amyloid \{beta protein in the Tg2576 transgenic mouse model of Alzheimer's disease. J. Neurosci. 21:372-381.

31. Takeda, K., et al. 2003. Progressive development of insulin resistance phenotype in male mice with complete aromatase (CYP19) deficiency. J. Endocrinol. 176:237-246.

32. McLaurin, J., et al. 2006. Cyclohexanehexol inhibitors of Abeta aggregation prevent and reverse Alzheimer phenotype in a mouse model. Nat. Med.
12:801-808.

33. Vallet, P.G., et al. 1992. A comparative study of histological and immunohistochemical methods for neurofibrillary tangles and senile plaques in Alzheimer's disease. Acta Neuropathologica. 83:170-178.

34. Ho, L., et al. 2004. Diet-induced insulin resistance promotes amyloidosis in a transgenic mouse model of Alzheimer's disease. FASEB J. 18:902-904.

35. Qiu, W.Q., et al. 1998. Insulin-degrading enzyme regulates extracellular levels of amyloid beta-protein by degradation. J. Biol. Chem. 273:32730-32738.

36. Zhao, Z., et al. 2005. Connective tissue growth factor (CTGF) expression in the brain is a downstream effector of insulin resistance- associated promotion of Alzheimer's disease beta-amyloid neuropathology. FASEB J. 19:2081-2082.

37. Lopez-Ongil, S., et al. 2005. Crosstalk between mesangial and endothelial cells: angiotensin II down-regulates endothelin-converting enzyme 1 . Cell. Physiol. Biochem. 15:135-144.

38. Takahashi, M., et al. 1995. Localization of rat endothelin-converting enzyme to vascular endothelial cells and some secretory cells. Biochem. J. 311:657-665.

39. Martindale. 2007. The complete drug reference. The Pharmaceutical Press. http://www.medicinescomplete.com $/ \mathrm{mc} / \mathrm{martindale} /$ current/contents.htm. 